\title{
Content and Language Integrated Learning Practices in Kazakhstan Secondary Schools During COVID-19 Pandemic
}

\author{
Gulzhana Kuzembayeva \\ Department of English and German Languages, K. Zhubanov Aktobe Regional University, Aktobe, \\ Kazakhstan \\ ORCID: 0000-0001-8964-3683
}

Akmaral Umarova

Department of Russian Language and Literature, Institute of Philology and Multilingual Education, Abai Kazakh National Pedagogical University, Almaty, Kazakhstan

ORCID: 0000-0002-8528-4131

Zhumagul Maydangalieva

Department of Foreign Languages and Literature, Baishev University, Aktobe, Kazakhstan

ORCID: 0000-0003-3189-8880

Olga Gorbatenko

Law Institute, Department of Foreign Languages, RUDN University, Moscow, Russia

ORCID: 0000-0001-5591-3948

Elena Kalashnikova

Law Institute, Department of Foreign Languages, RUDN University, Moscow, Russia

ORCID: 0000-0002-7861-6273

Nadezhda Kalmazova

Department of Foreign Languages, Law Institute, RUDN University, Moscow, Russia

ORCID: 0000-0002-5406-0581

Oksana Chigisheva

Department of Education and Pedagogical Sciences, Academy of Psychology and Pedagogy, Southern

Federal University, Rostov-on-Don, Russia

Chair on Global Education, Institute for Strategy of Education Development of the Russian Academy of

Education, Moscow, Russia

ORCID: 0000-0003-3358-2898

Received: 4 Nov 2021

Accepted: 19 Jan 2022

\begin{abstract}
A case study was initiated from the perspective of three research questions: 1) CLIL teachers' practices at secondary schools of Aktobe during COVID-19 pandemic; 2) challenges for the teachers; 3) support provided for the teachers. The research methodology combined face-to-face personal interviews, and non-participant observation. Data analysis was conducted in line with Mayring's (2020) approach to content analysis and by means of categorization into specific themes that emerge from teachers' conceptualization of their CLIL practices. The analysis of teachers' reflections on their experiences and challenges of using the CLIL approach during the pandemic, support provided to them and teachers' attitudes towards the approach is presented in the paper. Research data on the secondary schools Science teachers' CLIL practices in a remote learning setting was categorized related preparation to teaching, resources used by the teachers, students' interaction during the lessons, and stakeholders' attitudes and perceptions of the approach. The obtained data enables to understand Science teachers' practices in
\end{abstract}


terms of using the CLIL approach in Kazakhstani secondary schools in the period of COVID-19 pandemic, and will contribute to teacher development and preparation for successful CLIL realization in a nontraditional classroom.

Keywords: EFL, CLIL, science classroom, Kazakhstan, language policy, secondary school, pandemic, COVID19 , remote learning

\section{INTRODUCTION}

Speaking three languages - Kazakh, Russian and English - starting from - primary and secondary schools has become one of the leading issues in the field of education in Kazakhstan. In line with the policy for trilingual education development (2015-2020) it is expected that the knowledge of the English language will be advanced among the Kazakhstani students of primary and secondary schools by applying Content and Language Integrated Learning (CLIL) (Mehisto et al., 2014) in teaching Science Subjects such as Mathematics, Physics, Biology, Chemistry, Information Technology. In European practice, C. Dalton-Puffer (2007) considers the introduction of CLIL as one of the most commonly embraced solutions to transcend the perceived weakness of a traditional foreign language teaching, and thereby meet the- objective to acquire two foreign languages. Therefore, in most European educational systems the implementation of CLIL programs has become a commonplace (Pladevall-Ballester \& Vallbona, 2016). During early 2000s, several Asian countries tried to implement trilingual education at primary and secondary schools (Wang \& Kirkpatrick, 2012), but not all of them were successful. The introduction of CLIL into Russian practice has been controversial (Pavenkov \& Pavenkova, 2016).

In fact, Kazakhstan is the first Central Asian country to introduce CLIL for using three different languages as a medium of instruction for different content subjects as part of an ambitious national language-in-education policy (Karabassova, 2018). The statistical data of the Ministry of Education and Science of Kazakhstan shows that in 2016, 63,000 students in 117 primary and secondary schools of Kazakhstan (2.3\% of the total number of students) were practicing trilingual education (Sharipbayeva, 2017). A network of specialized Nazarbayev Intellectual Schools and Schools with Trilingual Education has been established in the country, in which Mathematics, Physics, Chemistry and Biology are taught in English (Kuzembayeva et al., 2018; Tkáčová et al., 2021).

Therefore, selected schools, such as Lyceums Bilim Innovation (former Kazakh-Turkish Lyceums), state trilingual schools and Network of Nazarbayev Intellectual Schools (NIS, 2014) are implementing various methods to teach Kazakh through the content of Social Science subjects, such as Geography and History (Mehisto et al., 2014). NIS schools are trying CLIL in subjects that are taught in Kazakh, Russian and English (NIS, 2014). Geography, History of Kazakhstan, Kazakhstan in the Modern World and Law Essentials are among subjects that integrate the content and language using the CLIL approach.

Discussion and analysis of Language Policy in Kazakhstan promoted the need to determine CLIL practices in the times of COVID-19, in order to understand realization of CLIL in secondary schools, challenges and successes, attitudes and perceptions from the teachers' perspective in the Kazakhstani context during the pandemic times. Kazakhstani schools transferred to remote learning in March 2020 - due to the spread of coronavirus around the country. As a result, students, teachers and school administration had to implement online learning tools such as Zoom, Moodle, Bilim Land, Google for Education, etc. as in many other countries of the world (Chigisheva et al., 2021; Soltovets et al., 2021). Shifting a CLIL-designed classroom from a traditional setting to an online one produces challenges in enhancing student interaction and conducting group activities (Birdsell, 2021).

Ethnographic research in education - fostered by globalisation and neoliberal forces- continued by studying Science teachers' CLIL practices through a Critical Sociolinguistic Ethnography (Heller \& Martin-Jones, 2001; Martín Rojo, 2010; Patiño-Santos, 2016; Rampton, 2006). As stated by Breidbach and Medina-Suárez (2014), since the so-called social turn (Block, 2003) in Applied Linguistics, teacher development research has increasingly focused on teachers' identities (Varghese et al., 2004). Despite numerous research outcomes on CLIL benefits (Jimenez Catalan \& Ruiz de Zarobe, 2009; Lorenzo et al., 2010), there are some critical points of 
CLIL implementation as ambiguity of defining CLIL or lack of CLIL materials (Birdsell, 2020). It is important to understand in which way teachers involved in CLIL are supported (or not) as language or content teachers, as classroom practitioners following learner-centred or subject-centred pedagogies, or as educators who see themselves as embedded in a relevant community of practice or as individual performers without much support from an imagined or factually existing group of peers (Breidbach \& Medina-Suárez, 2014). Investigation into CLIL teachers' practices is especially relevant in the times of COVID-19, as it will throw light on teachers' reflections on their practices, conceptualizations and attitudes towards CLIL in pandemic, and make sense in the successful realization of CLIL in the situations requiring remote learning.

\section{MATERIALS AND METHODS}

A case study was employed to best suit the purpose of the research stating three research questions:

1. What are the practices of Secondary Science teachers in relation of CLIL during COVID-19 pandemic?

2. What are the challenges for teachers in teaching practice using CLIL?

3. What kind of support is available for the CLIL teachers?

Case studyoffers the opportunity to 'unpack' issues, to see what they are about or what lies inside, and to explore how they are understood by those connected with them (Ritchie \& Lewis, 2013), enables to investigate a contemporary phenomenon within its real-life context (Yin, 1989, p. 23). We agree with Bonnet (2009) that studies into CLIL should "combine 2Qs, i.e. quantitative and qualitative approaches" (p. 76). Collecting qualitative and quantitative data is useful in providing "a condensed understating of a problem as well as detail" (Creswell, 2008, p. 565). It is considered "one of the strengths of case studies" by Demetriou (2013). Moreover, the subjectivity of the researcher as a potential limitation of the case study will be eliminated by applying different evidence sources, both quantitative and qualitative (Yin, 1989).

The research methodology combined face-to-face personal interviews, and non-participant observations. Utilizing interview and observation was aimed at collecting qualitative data, and complement it with quantitative findings.

For the purpose of the proposed research, two schools of Aktobe city (Al-Farabi specialized gymnasium No. 21 and Nazarbayev Intellectual School) have been selected due to the following major reasons:

- Both schools have trilingual education system as at current date;

- Al-Farabi specialized gymnasium No. 21 is a public school which is a good representative of all other public schools throughout the country, which are to implement trilingual education by 2020;

- Nazarbayev Intellectual School was one of the first schools to adopt CLIL to create a trilingual environment to help students build their linguistic competence.

The strategy of purposeful sampling was used to select the participants for the present study. CLIL teachers at the Al-Farabi specialized gymnasium No. 21 comprise five people, and four of them were interviewed. Four teachers from NIS agreed to participate in the research. Overall, the interviewees comprised 8 teachers of the chosen research sites with experiences of CLIL varying from 6 months to 13 years (see Table 1). The CLIL practices of 3 teachers from the chosen sites were further observed. The selection of teachers for observation was conducted via the convenient sampling strategy. Upon our request to observe the CLIL lessons 1 teacher from NIS, and 2 teachers of the Al-Farabi specialized gymnasium No. 21 agreed to participate in the observation. All the respondents who gave their consent to participate in the study were informed about the primary objectives of the research.

Open and close-ended questions were designed according to the aim of research within the framework of the semi-structured face-to-face personal interviews with the CLIL teachers of the research sites. Questions included teachers' reflections on their experiences and challenges of using the CLIL approach during COVID19 pandemic, support provided to them, and teachers' attitudes towards the approach. The chosen method 
Table 1. Participant information

\begin{tabular}{|c|c|c|c|c|c|c|}
\hline Participant & Sex & Age & $\begin{array}{l}\text { Teaching experience } \\
\text { (overall/in English) }\end{array}$ & Subject & $\begin{array}{l}\text { Grades (1-4, } \\
5-9,10-11)\end{array}$ & School \\
\hline \multicolumn{7}{|l|}{ Interview } \\
\hline S1 & Male & 27 & $2 / 1$ year & Biology & $\begin{array}{l}5-9 \\
10-11\end{array}$ & $\begin{array}{l}\text { Al-Farabi specialized } \\
\text { gymnasium No. } 21\end{array}$ \\
\hline S2 & Female & Unknown & Unknown & Computer Science & $\begin{array}{l}5-9 \\
10-11\end{array}$ & $\begin{array}{l}\text { Al-Farabi specialized } \\
\text { gymnasium No. } 21\end{array}$ \\
\hline S3 & Male & 28 & $3 / 1$ year & Chemistry & $10-11$ & NIS \\
\hline S4 & Male & 24 & $2 / 1$ year & Chemistry & $5-9$ & NIS \\
\hline S5 & Female & 36 & $13 / 13$ years & Biology & $10-11$ & NIS \\
\hline S6 & Female & 24 & 2 years $/ 6$ months & Biology & $5-9$ & NIS \\
\hline S7 & Female & Unknown & $4 / 4$ years & Biology & $\begin{array}{l}5-9 \\
10-11\end{array}$ & $\begin{array}{l}\text { Al-Farabi specialized } \\
\text { gymnasium No. } 21\end{array}$ \\
\hline S8 & Male & 38 & $10 / 6$ years & Chemistry & $5-9$ & $\begin{array}{l}\text { Al-Farabi specialized } \\
\text { gymnasium No. } 21\end{array}$ \\
\hline \multicolumn{7}{|c|}{ Observation } \\
\hline S9 & male & 28 & $3 / 1$ year & Chemistry & $10-11$ & NIS \\
\hline S10 & male & 38 & $10 / 6$ years & Chemistry & $5-9$ & $\begin{array}{l}\text { Al-Farabi specialized } \\
\text { gymnasium No. } 21\end{array}$ \\
\hline S11 & male & 27 & $2 / 1$ year & Biology & $\begin{array}{l}5-9 \\
10-11\end{array}$ & $\begin{array}{l}\text { Al-Farabi specialized } \\
\text { gymnasium No. } 21\end{array}$ \\
\hline
\end{tabular}

of collecting research data, as well as non-participant observations on the teachers' daily practices conducted via Zoom, made it possible to obtain thorough and important findings.

Data analysis was conducted in line with Mayring's (2020) approach to content analysis and by means of categorization into specific themes that emerge from teachers' conceptualization of their CLIL practices. Thematic approach is considered to be "useful for theorizing across a number of cases: finding common thematic elements across research participants and the events they report" (Riessman, 2005, p. 3).

\section{RESULTS}

Seven categories emerged based on the answers from the teachers' interviews: preparation to teaching CLIL, resources used by the teachers, the teachers' challenges, available support for the teachers, students' interaction during the lessons, stakeholders' attitudes and perceptions of the approach, teachers' recommendations for fostering CLIL.

\section{Science Teachers' CLIL Practices in Secondary Schools during COVID-19 Pandemic}

Issues on preparation to teaching CLIL, resources used by the teachers, students' interaction during the lessons, stakeholders' attitudes and perceptions of the approach were integrated in the theme "Science teachers' CLIL practices in secondary schools during COVID-19 pandemic" under the first research question. The findings obtained from the observations helped to complement this theme.

\section{Preparation for Teaching CLIL}

In preparing for the CLIL lessons most of the interviewed teachers report that they pay attention to terminology first. Taking into consideration the students' level of English, teachers try to adapt the study texts, - and substitute the difficult terms for easier ones. During the lesson, after presenting the new terms in English, they brainstorm their meaning. The students are free to use the language they feel - comfortable with (S1).

Teachers try to present a wide range of materials to their students during the CLIL lessons: diagrams, PowerPoint presentations, audios with exercises (see Figure 1). 


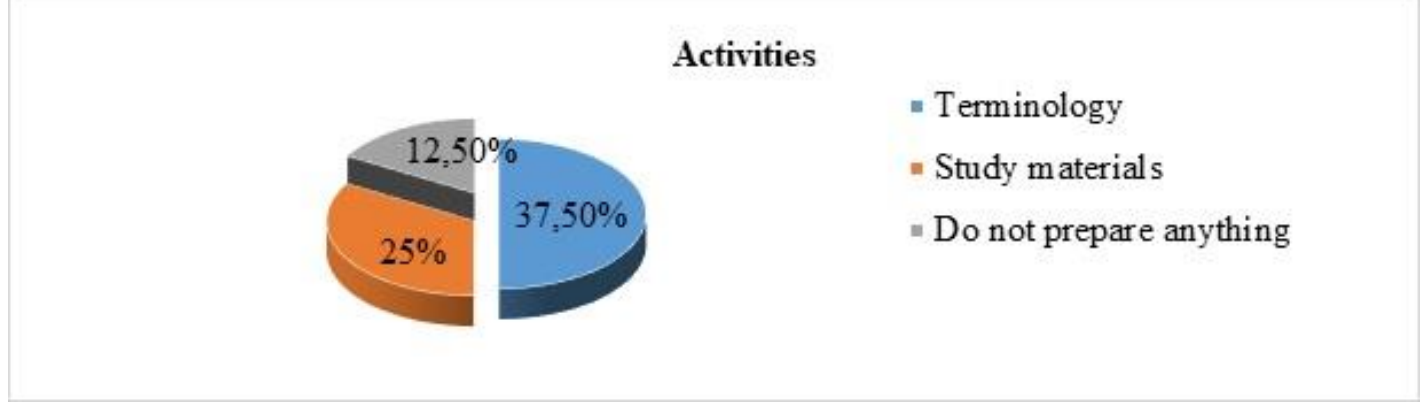

Figure 1. Preparation to CLIL lesson

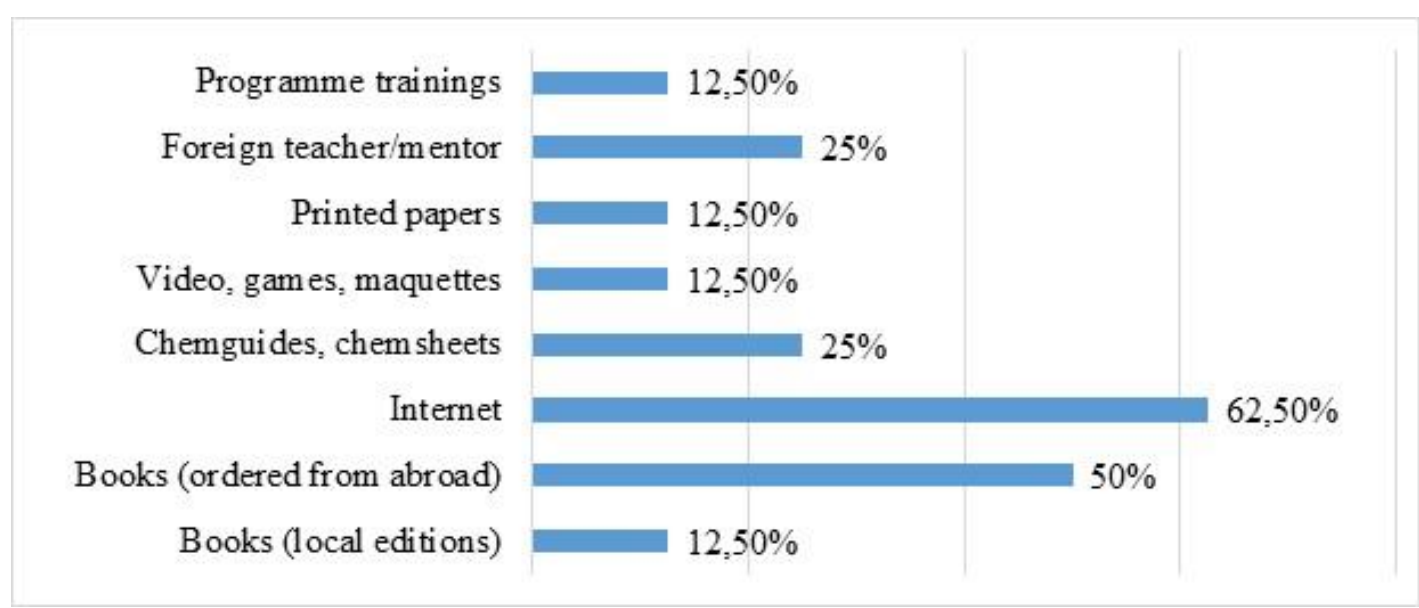

Figure 2. Resources available and used for preparing to CLIL lesson

Teachers' preparation for the CLIL lesson takes quite a long time (S2, S3, S4, S7). The problem of the time consuming preparation was solved after introducing books for the CLIL lessons, which contain the required study material. Preparing for the lesson now takes them from 20 to 40 minutes due to the - availability of resource books, language and methodology, and general support organized by the institution (S2).

\section{Resources Used by CLIL Teachers}

As it was noted in the previous subsection, for their CLIL lessons teachers use videos, games, maquettes and models. The books they use now contain different types of activities for the lesson to make them more interesting (S1). However, some teachers note that the books they use at the moment are not suitable in teaching high-performing students as the tasks they contain do not comply with the level of the students, and they don't have teachers' book (methods book) (S4). There are books printed abroad on the CLIL lessons methodology containing needed materials for the Science teachers. These books can be ordered via internet, though teachers have to pay from their own.

Thus, as the teachers are aimed at making their students engaged and interested in studying they have to bring into the lesson some additional material from the internet. According to the teachers, internet is another valuable source of study materials. There is a special website on the CLIL materials in Chemistry as http://chemsheets.com, which is considered to be very effective among Chemistry teachers. Shared web hosting http://pinterest.com and Cambridge study materials are also helpful. The only problem about finding extra study material is that using some websites is not free and requires annual purchases. Therefore, teachers have to pay for them from their own, as well as for any paper or printing. Resources used on CLIL lessons by the local teachers of secondary schools can be classified according to the Figure 2 . 


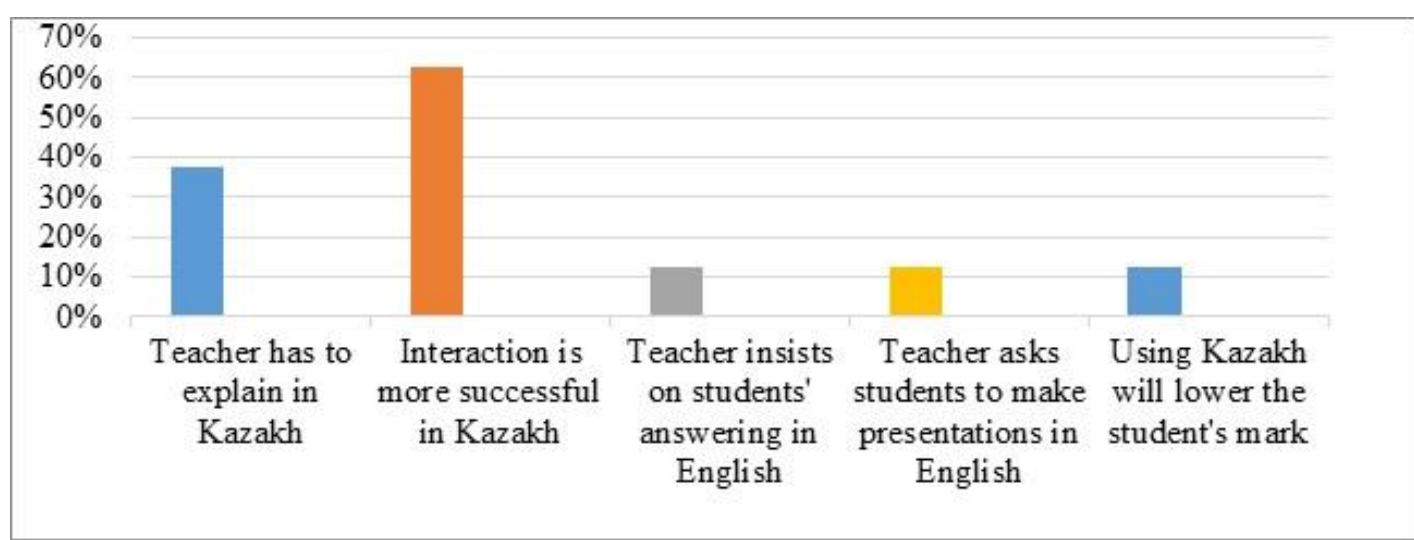

Figure 3. Students' interaction during CLIL lessons related to a language of instruction

\section{Students' Interaction during CLIL Lessons}

Analysis of teachers' interview answers indicate that students' different English language level in classes, their capabilities and desires to study leading to inefficient CLIL practices should be taken into consideration. Teachers use the students' mother tongue for explaining terminology and difficult concepts to make the students understand the theme and foster their classroom interaction (S1, S2, S7). However, teachers attempt to improve students' command of English and make them use more English while discussing at the lesson (S3). As an Al-Farabi Biology teacher states, students' classes at their school are divided into three groups and this makes easier to improve the students' foreign language skills.

According to our findings (see Figure 3), students interact freely during a CLIL lesson when teacher uses the students' mother tongue (62.5\%). Due to the students' level of language proficiency teachers have to explain in the Kazakh language (37.5\%). However, the interviewed teachers insist on students speaking English while answering the questions $(12.5 \%)$, and making presentations $(12.5 \%)$, as well as put lower marks if the students use Kazakh (12.5\%).

\section{Stakeholders' Attitudes and Perceptions of CLIL}

The first view on CLIL shared by most of the parents is negative. Parents consider using CLIL at secondary school setting difficult for students (S3), and note that Science subjects should first be mastered in students' mother tongue for better comprehension. However, at the same time parents understand the importance of speaking three languages nowadays (S3, S6), and support it for future aims as entering universities with English language instruction (S6, S7).

As for the students' perspectives according to the teachers interviewed, most of the students like the idea of CLIL, interested, and engaged to learn. (S3), despite facing challenges (S4). It is necessary to mention that the selected research sites are specialized schools for high-performing, gifted children. They can say for sure that using CLIL at lessons is more involving compared to traditional classes.

Thus, concluding the findings obtained from the interviewed teachers on the stakeholders' perceptions of CLIL, according to the $67 \%$ of them most of the parents do not support the idea of CLIL. Parents consider learning through CLIL difficult (60\%). At the same time, some of the parents find CLIL necessary (20\%) and important (20\%) for the successful future of their children. As for the students, they are engaged (25\%) and happy (25\%) about CLIL and find it interesting (25\%).

Observation of teachers' CLIL lessons of selected secondary schools in a remote learning setting helped to obtain additional data within the Research Question 1. First, - research was conducted through participation in the lessons of two teachers of Science subjects at the Al-Farabi specialized gymnasium No. 21. - It was noticed that the observed CLIL lessons were planned - thoroughly. Both teachers demonstrated the understanding of the fact that a good lesson planning is essential to the process of effective CLIL teaching 
and learning. - It was found that the teachers' English language proficiency was sufficient for the planned CLIL activities. The teachers used the English language for the $50 \%$ of explaining the terminology and checking the home task, and other $50 \%$ of the lesson was conducted in students' L1. The classroom language used by the teachers complied with the comprehensive CLIL talking style.

As for the students' language skills, they - were found to be quite good at using the appropriate science terminology and as expected from their background are taught to use the terminology - correctly, though they face challenges in explaining the scientific concepts in their own words. The teachers supported explanation of the lesson concepts with PowerPoint presentations and used additional visuals like pictures, charts and graphs. Teaching and learning materials for the CLIL lesson selected by the teachers from the available resources were adequately presented to the students and covered all lesson parts.

For the observation of a CLIL lesson at NIS, the online learning space was designed using Zoom as the remote learning platform. The students were provided by both transcripts and links to online videos on topics related to the topics of their lessons. After some ice-breaking activities the students discussed the content of the video and responded to critical thinking questions prepared by the teacher.

The observed CLIL teacher is quite experienced in - their subject and the CLIL approach. The lesson was efficiently conducted according to the aims of the lesson set during the thorough planning. The study materials were selected quite to the topic; all the new concepts were introduced with the usage of visuals like tables and pictures obtained from the website chemsheets.com. The teacher felt themselves confident at the lesson. English was used as the language of instruction, and classroom discourse used by him was very appropriate and clear for the students. The teacher tried to explain the new science terminology in simple words in English so that each student of any language level could understand it. It was sighted that using only English during the lesson was not possible for the teacher as sometimes the teacher had to answer in Kazakh to some students - to clarify some points of the subject concepts and chemistry formulas.

The purpose of the interviews about the students' language barriers, was to uncover to what extent these issues are and -the students' eagerness to understand the new concepts became apparent as they were taking notes and clarifying notions. Of course, there were students who kept - silent during the lesson, but the teacher tried to encourage all the students' active participation. Various CLIL techniques were used by the teacher to evoke students critical thinking and creativity.

\section{DISCUSSION}

The obtained data enabled to understand Science teachers' practices in terms of using the CLIL approach in Kazakhstani secondary schools during COVID-19 pandemic that reflected overall positive perceptions of CLIL in a remote learning setting. This contradicted the results of research conducted in Russian universities, where teaching school subjects in English have not met clear support, and it was offered to reduce the amount of English discourse (Pavenkova et al., 2018).

Data of the study demonstrated the students' active interaction through different techniques as reflected in Koopman et al. (2014), Oattes et al. (2018), Van Kampen et al. (2018), Tugun et al. (2020), Villabona and Cenoz (2021) even in a remote learning setting. Results of studying pedagogical practices showing that students had enough opportunity to use English in CLIL classes contradict with those of other studies stating the challenges of using target language while studying content (Dalton-Puffer, 2007; Mahan et al., 2018; Villabona \& Cenoz, 2021).

Teachers' perceptions of CLIL link with the findings of Karabassova (2018) stating that teachers "prioritized content over language, assuming only an indirect role in facilitating students' language development". Teachers consider rendering terminology of the lesson properly more important than students' knowledge of English and can do it by means of using L1.

Critical issues of CLIL such as the lack of resources for preparing for the classes (Birdsell, 2020) are addressed by the fact that in CLIL classes, teachers and students have more opportunities to use online resources and 
materials outside the classroom being able to benefit from the materials in English. The lack of teacher training is challenging for CLIL teachers of science subjects which was also reported by Fernández-Barrera (2019).

The findings on the significance of peer-collaboration agree with the previous CLIL teacher research (Breidbach \& Medina-Suárez, 2014; Capone et al., 2017; Hüttner et al., 2013; Massler, 2012) and importance of professional development education for teacher development (Goris, 2009).

\section{CONCLUSION}

Overall, the pedagogical practices of Kazakhstani secondary school Science teachers in relation to CLIL in COVID-19 pandemic are efficient. The teachers interviewed and observed demonstrated a well-organized and resourceful realization of CLIL lessons even in a different than a traditional setting.

The students showed motivation and eagerness to interact during the on-line lessons due to their understanding of the importance of CLIL for their progress, and the teachers tried to evoke students' critical thinking and creativity. The challenges in practicing CLIL according to the interviewed teachers are mostly in using classroom language and students' language barrier.

The support provided for the CLIL teachers in teaching Science subjects at the secondary schools includes intensive language training, guidance of foreign experts and mentoring system, organization of CLIL courses abroad, online courses, sharing good practices and cooperative work, and financial motivation.

The results of study suggest that studying Science subjects through CLIL approach expand intellectual horizons of students while improving their English language skills and knowledge adapting CLIL to new teaching environments and situations.

Author contributions: All authors were involved in concept, design, collection of data, interpretation, writing, and critically revising the article. All authors approve final version of the article.

Funding: The authors received no financial support for the research and/or authorship of this article.

Declaration of interest: Authors declare no competing interest.

Data availability: Data generated or analysed during this study are available from the authors on request.

\section{REFERENCES}

Birdsell, B. J. (2020). A review of the critical literature on CLIL and steps to move Japan CLIL forward. The Journal of the Japan CLIL Pedagogy Association, 2, 110-126.

Birdsell, B. J. (2021). CLIL in the times of COVID-19: Content, communication, and creative cognition in remote learning. The Journal of the Japan CLIL Pedagogy Association, 3, 134-149.

Block, D. (2003). The social turn in language acquisition. Edinburgh UP.

Bonnet, A. (2009). Die dokumentarische methode in der empirishen unterrichtsforshung. Ein integratives forshungsinstrument fur strukturrekonstruktion und kompetenzanalyse [The documentary method in empirical educational research. An integrative research tool for structural reconstruction and competency analysis]. Zeitschrift fur qualitative Forschung, 10(2), 223-240.

Breidbach, S., \& Medina-Suárez, J. (2014). Teachers' perspectives on CLIL and classroom innovation in a method based on drama games. Estudios Sobre Educación, 31, 97-116. https://doi.org/10.15581/004.31.97-116

Capone, R., Del Sorbo, M. R., \& Fiore, O. (2017). A flipped experience in physics education using CLIL methodology. Eurasia Journal of Mathematics, Science and Technology Education, 13(10), 6579-6582. https://doi.org/10.12973/ejmste/77044 
Chigisheva, O., Soltovets, E., Dmitrova, A., Akhtyan, A. G., Litvinova, S. N., \& Chelysheva, Y. V. (2021). Digital literacy and its relevance to comparative education researchers: Outcomes of SciVal analytics. Eurasia Journal of Mathematics, Science and Technology Education, 17(10), em2017. https://doi.org/10.29333/ejmste/11183

Creswell, J. W. (2008). Educational research: Planning, conducting, and evaluating quantitative and qualitative research. Pearson.

Dalton-Puffer, C. (2007). Discourse in Content and Language Integrated Learning (CLIL) classrooms. John Benjamins Publishing Company. https://doi.org/10.1075/IIIt.20

Demetriou, H. (2013). The case study (2nd ed.). In E. Wilson (Eds.), School-based research: A guide for education students. Sage.

Goris, J. A. (2009). English in mainstream European secondary schools: Content and Language Integrated Learning (CLIL). In D. Marsh, P. Mehisto, D. Wolff, R. Aliaga, T. Asikainen, M. J. Frigols-Martin, S. Hughes, \& G. Langé (Eds.), CLIL practice: Perspectives from the field (pp. 28-33). University of Jyväskylä.

Heller, M., \& Martin-Jones M. (2001). Voices of authority: Education and linguistic difference. Ablex Publishing.

Hüttner, J., Dalton-Puffer, C., \& Smit, U. (2013). The power of beliefs: Lay theories and their influence on the implementation of CLIL programmes. International Journal of Bilingual Education and Bilingualism, 16(3), 267-284. https://doi.org/10.1080/13670050.2013.777385

Jimenez Catalan, R. M., \& Ruiz de Zarobe, Y. (2009). The receptive vocabulary of EFL learners in two instructional contexts: CLIL versus non-CLIL. Content and language integrated learning. Evidence from research in Europe. Multulingual Matters. https://doi.org/10.21832/9781847691675-008

Karabassova, L. (2018). Teachers' conceptualization of content and language integrated learning (CLIL): evidence from a trilingual context. International Journal of Bilingual Education and Bilingualism, 21(7), 1-13. https://doi.org/10.1080/13670050.2018.1550048

Koopman, G. J., Skeet, J., \& de Graaff, R. (2014). Exploring content teachers' knowledge of language pedagogy: A report on a small-scale research project in a Dutch CLIL context. Language Learning Journal, 42(2), 123-136. https://doi.org/10.1080/09571736.2014.889974

Kuzembayeva, G., Karimsakova, A., \& Kupenova, A. (2018). Trilingualism in Kazakhstan. International Journal of Multilingual Education, 11, 87-90. https://doi.org/10.22333/ijme.2018.110013

Lorenzo, F., Casal, S., \& Moore, P. (2010). The effects of content and language integrated learning in European education: Key finding form Andalusian sections evaluation project. Applied Linguistics, 31, 418-428. https://doi.org/10.1093/applin/amp041

Mahan, K. R., Brevik, L. M., \& Ødegaard, M. (2018). Characterizing CLIL teaching: New insights from a lower secondary classroom. International Journal of Bilingual Education and Bilingualism, 24, 1-18. https://doi.org/10.1080/13670050.2018.1472206

Martín Rojo, L. (2010). Constructing inequality in multilingual classrooms. De Gruyter Mouton. https://doi.org/10.1515/9783110226645

Massler, U. (2012). Primary CLIL and its stakeholders: What children, parents and teachers think of the potential merits and pitfalls of CLIL modules in primary teaching. International CLIL Research Journal, 1(4), 36-46.

Mayring, P. (2020). Qualitative content analysis: Demarcation, varieties, developments. Forum Qualitative Sozialforschung: Qualitative Social Research, 20(3), 1-14. https://doi.org/10.17169/fqs-20.3.3343 
Mehisto, P., Kambatyrova, A., \& Nurseitova, A. (2014). Three in one? Trilingualism in educational policy and practice. In D. Bridges (Eds.). Educational reform and internationalization: The case of school reform in Kazakhstan. Cambridge University Press.

NIS. (2014). Nazarbayev Intellectual Schools: Godovoy otchet 2013. http://nis.edu.kz/ru/about/reports/?id=2815

Oattes, H., Oostdam, R., de Graaff, R., Fukkink, R., \& Wilschut, A. (2018). Content and Language Integrated Learning in Dutch bilingual education. Dutch Journal of Applied Linguistics, 7(2), 156-176. https://doi.org/10.1075/dujal.18003.oat

Patiño-Santos, A. (2016). Etnografía y sociolingüística [Ethnography and sociolinguistics]. In J. GutiérrezRexach (Ed.), Enciclopedia de lingüistica hispánica [Encyclopedia of hispanic linguistics]. Routledge. https://doi.org/10.4324/9781315713441-6

Pavenkov, O., \& Pavenkova, M. (2016). Discourse analysis based on Martin and Rose's taxonomy: a case of promoting student discourse on the CLIL PhD programme in religion philosophy. Revista Electrónica Espacio Teológico, 10(17), 129-139. https://doi.org/10.21710/rch.v17i0.288

Pavenkova, M., Pavenkov, O., \& Pavenkov, V. (2018). English, Russian and Russian English in Russia: CLIL and non-CLIL students' opinion in St. Petersburg. Revista Cientifica Hermes, 20, 133-152. https://doi.org/10.21710/rch.v20i0.340

Pladevall-Ballester, E. \& Vallbona, A. (2016). CLIL in minimal input contexts: A longitudinal study of primary school learners' receptive skills. System, 58, 37-48. https://doi.org/10.1016/j.system.2016.02.009

Rampton, B. (2006). Language in late modernity. Interaction in an urban school. Cambridge University Press. https://doi.org/10.1017/CBO9780511486722

Riessman, C. K. (2005). Narrative analysis. In N. Kelly, C. Horrocks, K. Milnes, B. Roberts, \& D. Robinson (Eds.), Narrative, memory \& everyday life. University of Huddersfield.

Ritchie, J., \& Lewis, J. (2013). Qualitative research practice - A guide for social science students and researchers. Sage.

Sharipbayeva, A. K. (2017). Deficiency of the trilingual education reform in Kazakhstan: Problems and prospects. Molodoi uchenyi, 10.1(144.1), 102-105.

Soltovets, E., Chigisheva, O., Dubover, D., \& Dmitrova, A. (2021). Russian digital education landscape during the current pandemic: is the impact felt? E3S Web of Conferences, 273, 12026. https://doi.org/10.1051/e3sconf/202127312026

Tkáčová, H., Pavlíková, M., Tvrdoň, M., \& Prokopyev, A.I. (2021). Existence and prevention of social exclusion of religious university students due to stereotyping. Bogoslovni Vestnik, 81(1),199-223. https://doi.org/10.34291/BV2021/01/Tkacova

Tugun, V., Bayanova, A. R., Erdyneeva, K. G., Mashkin, N. A., Sakhipova, Z. M., \& Zasova, L. V. (2020). The opinions of technology supported education of university students. International Journal of Emerging Technologies in Learning, 15(23), 4-14. https://doi.org/10.3991/ijet.v15i23.18779

Van Kampen, E., Admiraal, W., \& Berry, A. (2018). Content and language integrated learning in the Netherlands: Teachers' self-reported pedagogical practices. International Journal of Bilingual Education and Bilingualism, 21(2), 222-236. https://doi.org/10.1080/13670050.2016.1154004

Varghese, M. (2004). Professional development for bilingual teachers in the United States: A site for articulating and contesting professional roles. Bilingual Education and Bilingualism, 7(2/3), 222-237. https://doi.org/10.1080/13670050408667810 
Villabona, N., \& Cenoz, J. (2021). The integration of content and language in CLIL: A challenge for contentdriven and language-driven teachers. Language, Culture and Curriculum, 1, 1-15. https://doi.org/10.1080/07908318.2021.1910703

Wang, L., \& Kirkpatrick, A. (2015). Trilingual education in Hong Kong primary schools: An overview. Multilingual Education, 5, 3-12. https://doi.org/10.1186/s13616-015-0023-8

Yin, R. K. (1989). Case study research: Design and methods. Sage.

Correspondence: Gulzhana Kuzembayeva, PhD, Associate Professor, Department of English and German Languages, K. Zhubanov Aktobe Regional University, Aktobe, Kazakhstan. E-mail: kuzembayeva@mail.ru 